Zoología / Zoology

\title{
BUTTERFLIES (LEPIDOPTERA: PAPILIONOIDEA) OF LA HONDA BASIN, MESA DE LOS SANTOS, SANTANDER, COLOMBIA
}

\section{Mariposas (Lepidoptera: Papilionoidea) de la cuenca de La Honda, Mesa de Los Santos, Santander, Colombia}

\author{
Título corto: Butterflies of La Honda basin, Santander
}

\author{
Alfonso Villalobos-Moreno ${ }^{1}$ \\ Julián A. Salazar-Escobar ${ }^{2}$ \\ ' Doctor en Ciencias Agrarias, Director Grupo de Investigaciones \\ Entomológicas y Ambientales-GENA. Autor de correspondencia. \\ Calle 91 No. 22-104 Apto 403, Bucaramanga, Colombia; \\ e-mail: alfvillalmo@gmail.com, avillalobosmo@unal.edu.co; \\ ORCID: 0000-0003-1713-7823 \\ ${ }^{2}$ MVZ, Magister en Ciencias Biológicas, \\ Museo de Historia Natural, Universidad de Caldas; \\ e-mail: julianmantis@gmail.com; \\ ORCID: 0000-0003-2268-7803
}

\begin{abstract}
Colombia is a privileged country given the geographical position, the diversity of ecosystems and the great plant complexity, conditions that allow it to occupy the third place in diversity of diurnal butterflies. The objective of this work was to establish the composition of species of diurnal butterflies in four locations of the La Honda basin for which captures were made using entomological nets of $45 \mathrm{~cm}$ in diameter, in the project of Characterization of the wild Entomofauna of La Honda basin, located in the northeast of the Colombian Andes. Analysis of inventory quality and analysis of similarity between sampling sites were performed. A total of 226 specimens were
\end{abstract}

Historia del artículo

Fecha de recepción:

04/03/2020

Fecha de aceptación:

07/07/202O 
collected belonging to 95 species of the family Hesperiidae, Papilionidae, Pieridae, Lycaenidae, Riodinidae and Nymphalidae, the last having greatest abundance (134) and richness of species (53). La Navarra was the site with greatest abundance (110) and richness of species (54). The analysis of inventory quality indicated a potential richness of 167.13 species, a proportion of observed species of $56.24 \%$ and a sampling effort of $99.82 \%$. The comparison of inventories allowed establishing that butterfly communities are different for all sampling sites, although there is a slight similarity between La Navarra and La Purnia. Based on the analysis of the inventory quality, it is proposed to carry out new sampling for these and other locations, as well as at different times of the year.

Key words: Abundance and richness, Colombian Andean, analysis of similarity, butterflies.

\section{Resumen}

Colombia es un país privilegiado dada su posición geográfica, la diversidad de ecosistemas y la gran complejidad vegetal, condiciones que la ubican en el tercer lugar en diversidad de mariposas diurnas. El objetivo del presente trabajo fue establecer la composición de especies de mariposas diurnas en cuatro localidades de la cuenca de La Honda, para lo cual, se realizaron capturas utilizando redes entomológicas de $45 \mathrm{~cm}$ de diámetro, en el marco del proyecto de Caracterización de la Entomofauna silvestre de la cuenca de La Honda, que se ubica en el nororiente de los Andes colombianos. Se realizaron análisis de la calidad del inventario y de similitud entre los sitios de muestreo. Se colectaron 226 ejemplares pertenecientes a 95 especies de las familias Hesperiidae, Papilionidae, Pieridae, Lycaenidae, Riodinidae y Nymphalidae, esta última con mayor abundancia (134) y riqueza de especies (53). La vereda La Navarra fue el sitio con mayor abundancia (110) y mayor riqueza de especies (54). El análisis de la calidad del inventario indicó una riqueza potencial de 167,13 especies, una proporción de especies observadas del $56,24 \%$ y un esfuerzo de muestreo del 99,82\%. La comparación de los inventarios permitió establecer que las comunidades de mariposas son diferentes para todos los sitios de muestreo, aunque se observa una leve similitud entre La Navarra y La Purnia. Con base en el análisis de la calidad del inventario se propone la realización de nuevos muestreos para estas y otras localidades, así como en diferentes épocas del año.

Palabras clave: Abundancia y riqueza; Andes colombianos; análisis de similitud; mariposas diurnas.

\section{Introduction}

Colombia is a privileged country in biodiversity due to its geographical position, variety of ecosystems and great vegetal complexity, which ranks it in the third place in the world in butterflies diversity with more of 3,780 species, grouped in the families Hesperiidae, Papilionidae, Pieridae, Nymphalidae, Riodinidae and Lycaenidae (Andrade-C, 1990; Andrade-C, 
2011; Huertas \& Arias, 2007; Lamas, 2004; Rangel-Ch, 1995). Department of Santander, and northeaster of Colombia, has been few studied, and has fragmented studies and isolated samplings in degree works, pedagogical outputs, consulting and projects of characterization. In this way, there are still areas of Colombian Andes that have a lot of information in biological and environmental terms (Agudelo \& Pérez, 2015; Arbeláez-Cortez, 2013; Campos et al., 2011; Pardo-Locarno \& Villalobos-Moreno, 2016; Villalobos-Moreno, 2013, 2017; VillalobosMoreno et al., 2012, 2013; Villalobos-Moreno \& Gómez, 2015; Villalobos-Moreno \& Salazar, 2020a).

The biodiversity crisis requires tools to evaluate the natural environmental using different methodologies, which has allowed developing the concept of bioindicator, apply rapid evaluation techniques and use of nonparametric estimators, with the above, has been possible to reduce the research time and the cost (Oliver \& Beattie, 1996). The butterflies are important bioindicators due to the utility to establish the state of the environment in diversity parameters or human intervention degree. In addition, these are used in ecological studies, because certain species indicate changes in variables such as sunshine, temperature, microclimate and humidity, parameters that are drastically altered in disturbed habitats (Brown \& Freitas, 2002; Constantino, 1997; Ramírez et al., 2007). The preference that exist to study butterflies is based on the great attractiveness, abundance and ease of encounter, endemism, space-time stability, ecological sensitivity, easy field handling and taxonomical stability (Brown, 1991; Kremen, 1992, 1994; Kremen et al., 1994; Llorente \& Martínez, 1998; Ospina-López, 2014). Finally, it is widely known that the degradation of wild areas contributes to extinction of many species of butterflies, particularly critical in the Andean area due to the extension of the agricultural and urban frontier (Maso \& Piojan, 1997; Palacios \& Constantino, 2006).

The objective of the present investigation was to contribute to the knowledge of structure and composition of butterfly communities in four rural areas (veredas) in La Honda basin in the northeaster Andes of Colombia. We provide data about composition, abundance and distribution of butterflies in the study area, basic information that will be used to carry out in-depth works and, if possible, it will be an important resource for to establish preservation programs in this zone.

\section{Materials and methods}

\section{Study area}

La Honda basin has an area of 1,782 hectares and almost 40 kilometres of perimeter. This basin form part of Sogamoso river basin and it is a natural limit between the municipalities of Los Santos and Piedecuesta; it supplies water to, at least, eight rural areas (veredas) of the 28 existing ones, principally to agricultural work (Calderón, 2011). La Honda basin is south to Bucaramanga, capital of department of Santander, and northeaster of Colombian Andes (Fig. 1). Although much of the basin is highly intervened with cow pastures, varied 

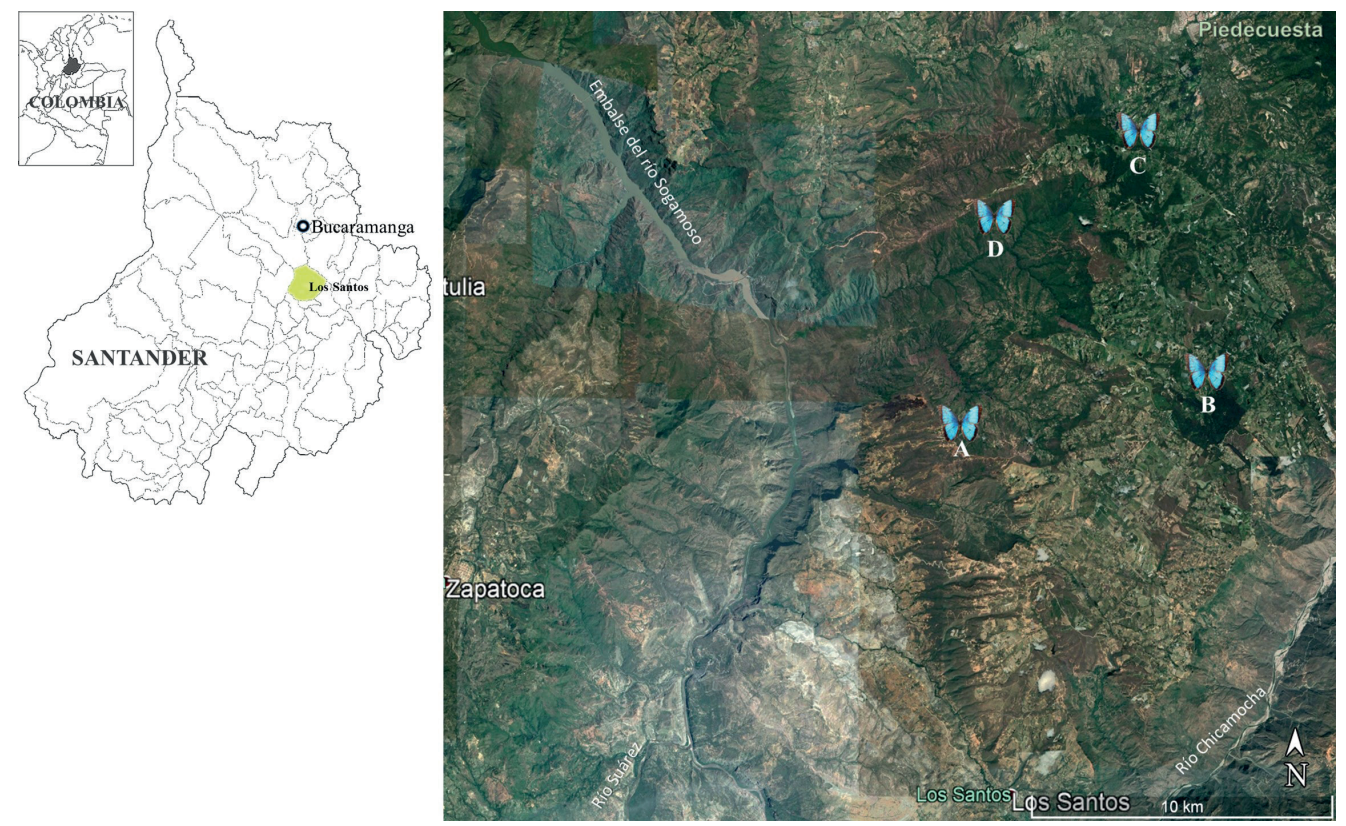

Figure 1. Location of the sampling places in La Honda basin, Mesa de Los Santos, Santander, Colombia. A: La Purnia; B: Cacaos; C: La Navarra; D: San Javier (Adapted of Google Earth Pro).

agricultural crops, sheds for chickens, mining, tracks and urbanized areas. We established the sampling places in four rural areas (veredas), one in an agroecological coffee crop with tree cover, another one in a relatively preserved forest and two others in fragmented forest (Fig. 2). The sampling places are described below:

- Locality 1 - Vereda Cacaos: $6{ }^{\circ} 51^{\prime} 39.75 ” \mathrm{~N}$, $73^{\circ} 02^{\prime 2} 29.99 " W ; 1,700$ masl. This sampling place corresponds to a mature coffee plantation with 15 years. It present high vegetal cover with a canopy greater than $15 \mathrm{~m}$. According to Holdridge (2000), it corresponds to a Tropical rain forest (bh-T by the initials in Spanish). According to
Cuatrecasas (1989), it corresponds to a sub-Andean jungle.

- Locality 2 - Vereda La Navarra: $6{ }^{\circ} 56^{\prime} 08.04 ” \mathrm{~N}, \quad 73^{\circ} 04$ '21.96”W; 1,510 masl. This sampling place corresponds to a Tropical rain forest (bh-T) (Holdridge, 2000), or a sub-Andean jungle (Cuatrecasas, 1989). The vegetal cover is relatively well preserved, although fragmentation processes are evident in its periphery.

- Locality 3 - Vereda La Purnia: $6^{\circ} 53^{\prime} 07.27 ” \mathrm{~N}, \quad 73^{\circ} 06^{\prime} 32.90 ” \mathrm{~W} ; \quad 1,237$ masl. According to Holdridge (2000), this sampling place corresponds to a Tropical dry forest (bs-T by the 

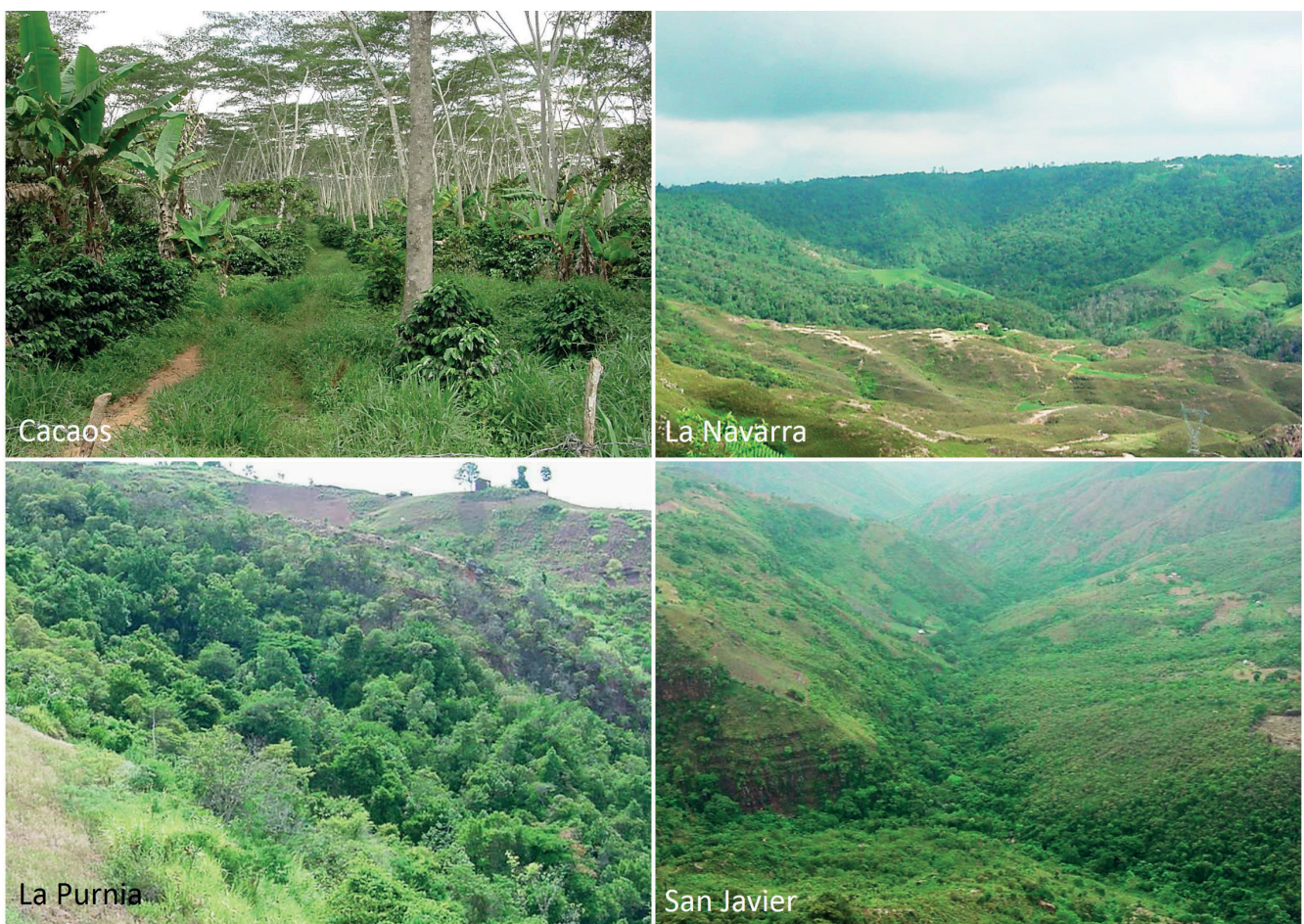

Figure 2. General view of sampling places in La Honda basin, Mesa de Los Santos, Santander, Colombia.

initials in Spanish) transitional to a Tropical rain forest (bh-T). According to Cuatrecasas (1989), it corresponds to a Neotropical lower jungle with elements of sub-Andean jungle. It is a secondary forest with evident fragmentation processes and very small forest relics.

- Locality 4-Vereda San Favier: 6 55’23.51”N,

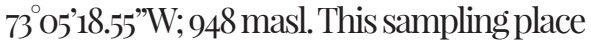
corresponds to a Tropical dry forest (bsT) (Holdridge, 2000), or a Neotropical lower jungle (Cuatrecasas, 1989). It is a secondary forest with fragmentation processes, which include forest clearing and burn to establish crops and livestock.

\section{Sampling and identification}

We carried out butterfly sampling in the project Characterization of Entomofauna of La Honda basin, jurisdiction of the Regional Autonomic Corporation for Defense of Bucaramanga Plateau (CDMB). Four sampling areas were established between 948 and 1,700 masl. The sampling was done five days in each area in routes with undefined extension. Two people made 
the collections using entomological nets of $70 \mathrm{~cm}$ of diameter, between 9:00 am and 5:00 pm, for a total sampling effort of 80 hours/locality. Further, at each sampling place, six van Someren-Rydon traps baited with decomposing banana were installed, which were checked every four hours, for a total sampling effort of 720 hours/locality. The collected specimens were stored in dove paper envelopes and taken to the CDMB laboratory and were assembled, labelled and stored in Schmitt (Triplehorn \& Johnson, 2005). The taxonomical determination was made with the keys and illustrations of Le Crom et al. (2002, 2004) and Neild (1996, 2008), as well as by comparison in Entomological Collection of Institute of Natural Sciences of National University of Colombia, Bogotá. The species were organized based on Lamas (2004).

\section{Analysis of inventory quality}

We carried out an analysis of sampling effort to establish the level of knowledge regarding inventory of species and to predict the potential richness in the sampling area. We considered as unit of sampling effort (USE) to the sum of data of each sampling day, therefore, 20 USE were established. Through the EstimateS program (Colwell, 200o), data entry was randomized (1,00o iterations) to avoid bias in calculation of observed richness. To predict the potential richness, we used the nonparametric Chaor (based in abundances), as it is a robust estimator of minimum richness and, usually, offers better results than others estimators (Gotelli $\&$ Colwell, 2001; Walther \& Moore, 2005).
Using the CurveExpert program (Hyams, 2009), the estimates were adjusted to a Clench asymptotic curve, to calculate the different parameters of the curve (JiménezValverde \& Hortal, 2003).

Structure and composition of butterfly communities at sampling places

Using the values of abundance and richness observed in each of the sampling localities, were established for each of these, the series of diversity numbers of Hill: No $=$ potential richness, $\mathbf{N} \mathbf{i}=$ diversity of order 1 (exponential of Shannon-Wiener index: $\left.e H^{\prime}\right)$ and $\mathbf{N} \mathbf{2}=$ diversity of order 2 (inverse of Simpson index: 1/DSi) (Moreno et al., 2011; Núñez \& Barro 2003; Villalobos-Moreno \& Salazar, 202ob; Villalobos-Moreno et al., 2016). The potential richness (No) was calculated with a similar procedure to the analysis of sampling effort, coinciding this richness with the asymptote of curve adjusted of Clench (Colwell, 2000; Hyams, 2009). The diversities of order 1 $(\boldsymbol{N i})$ and order $2(\mathbf{N 2})$ was calculated with the program Spade (Chao \& Shen, 2009), which offers these values, together with its standard deviation. The diversity numbers of Hill, which have as a unit the number of species, measure the effective number of species presents and these are a measure of distribution degree of relative abundances between the species of a sampling. No corresponds to the total number of species, $\mathcal{N i}$ is the number of abundant species and $\mathcal{N} 2$ is the number of very abundant species $\left(\mathrm{No}^{\circ} \mathrm{N}_{1}>\mathrm{N}_{2}\right)$ (Jost, 2010). 


\section{Comparison between sampling places}

With the purpose of establishing possible differences between sampling areas within La Honda basin, the inventory of taxa reported for each sampling place. Using a presence-absence matrix and the PRIMER 6 v6.1.6 program (PRIMER-E Ltd., 2006), the distances of Bray-Curtis were calculated and the respective phenogram was constructed using an average grouping method, thus estimating the possible similarity between the sampling areas (Ludwig \& Reynolds, 1988; Magurran, 1988).

\section{Results and discussion}

We collected 226 specimens belonging to 95 species, grouped in the families Hesperiidae, Papilionidae, Pieridae, Lycaenidae, Riodinidae and Nymphalidae (Appendix 1). The family Nymphalidae was the best represented in all sampling places, and with the greatest abundance (134) and richness of species (53) (Fig. 3), given that this group has a wide geographical distribution, generalist habits, a high proportion of species and easy adaptation to disturbed environments (DeVries, 1987). La Navarra, perhaps due the extension and quality of the forest, presented the highest values of diversity, with the highest abundance (110) and richness of species (54), followed by La Purnia with 52 specimens and 38 species reported (Fig. 4).

Casa-Pinilla et al. (2017) carried out an investigation in La Mesa de Los Santos in an altitude range between 280 and 1,200 masl. They collected 1,389 specimens belonging to 121 species and the same families, except Hesperiidae that was not reported. The present manuscript has 35 species in common with Casa-Pinilla et al. (2017),

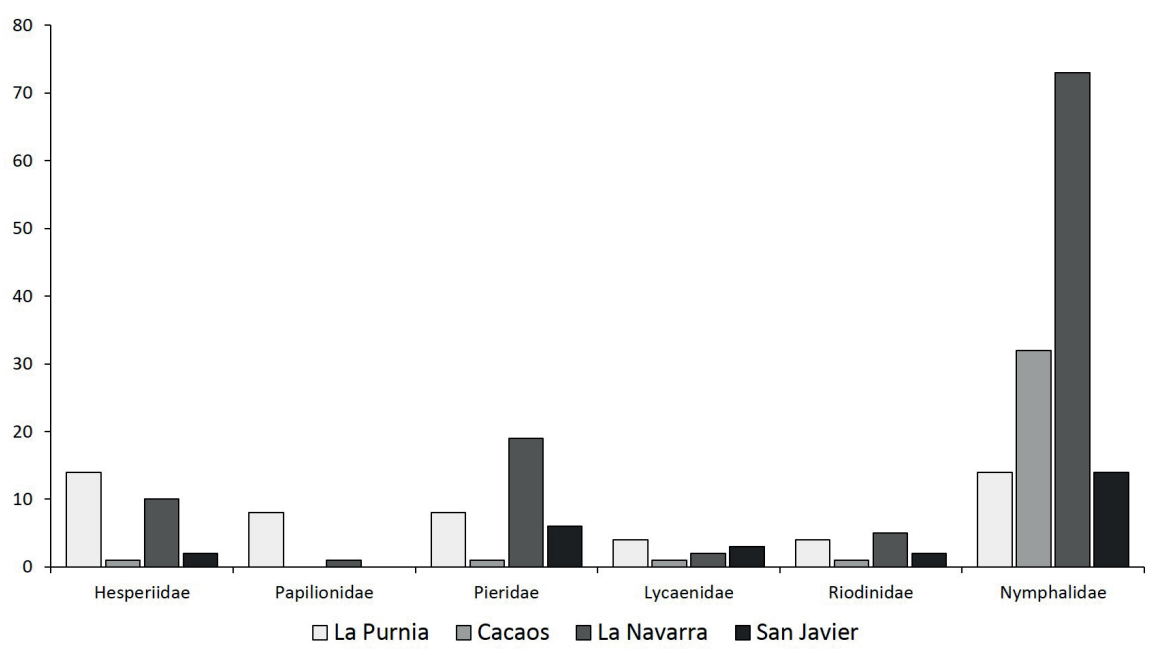

Figure 3. Abundance of the families of butterflies in the sampling places. 


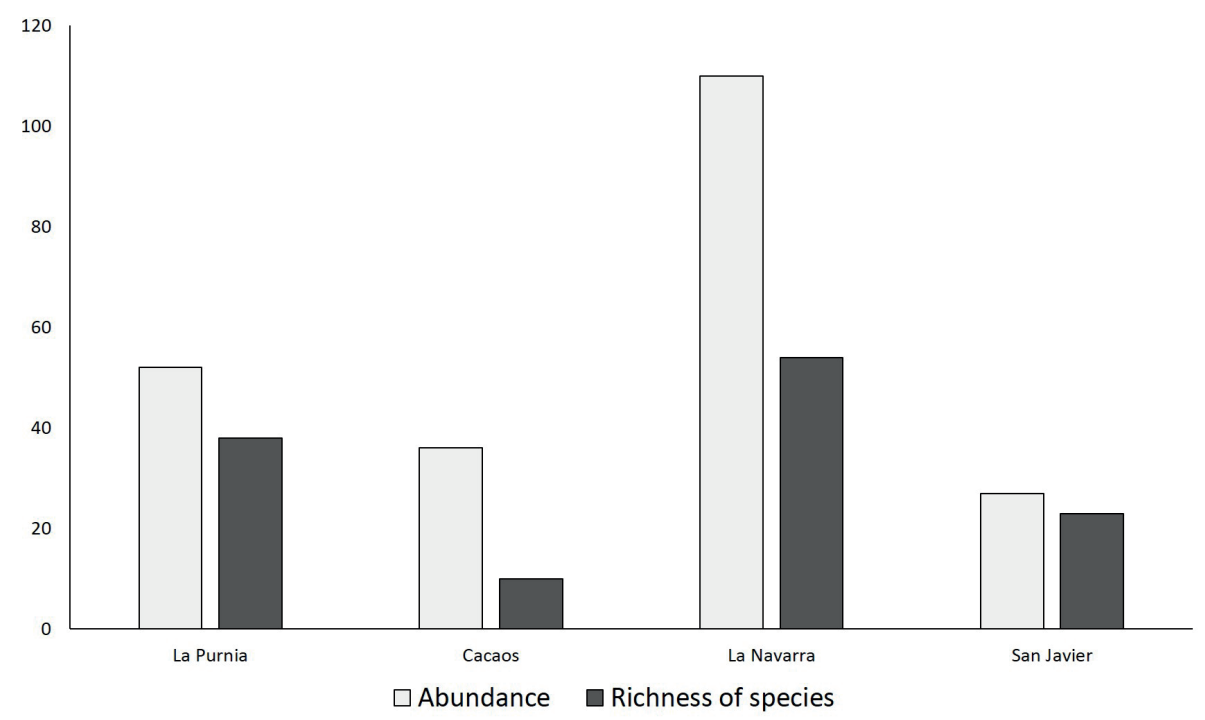

Figure 4. Abundance and richness of species in the sampling places.

the most of which are those registered for the low areas. Another explanation for not having more species in common, may be related to the phenology of species and the season of the year in which the samplings were carried out. In this way, it could be affirmed that both works are complementary in terms of species inventory and altitude gradient; Casa-Pinilla et al. (2017) sampled between 280 and 1,200 masl and the present manuscript presents results of a gradient between 948 and 1,700 masl. In this order of ideas, both works are complementarity to better understand the composition of the lepidopterofauna of the area.

Appendix 1 presents the list of species in the study area, classified under abundant species: more of 10 records; common species: $6-10$ records; scarce species: 2-5 records; and rare species: only one record (Fagua, 1996; Henao, 2006; Henao
$\&$ Stiles, 2018). We observed that only $2.11 \%$ of species were abundant, while $3.16 \%$ were common, $48.41 \%$ were scarce and $46.32 \%$ rare. The species with greatest abundances were Euptychoides saturnus (26) and Hermeuptychia hermes (11). On the other hand, 43 species were represented by only one specimen and they were considered in the category rare, for example Adelpha irmina, Arawacus togarna, Archaeoprepona demophon, Catonephele numilia, Dismorphia amphione, Dismorphia crisia, Doxocopa pavon, Dynamine artemisia, Euptoieta claudia, Hamadryas feronia, Hamadryas fornax, Heraclides astyalus, Leucochimona lepida, Pseudopieris nehemia, Pseudopieris viridula and Rekoa meton.

Appendix 2 shows some species of butterflies collected in La Honda basin. Most of the collected species are widely distributed and have historically been recorded for open 
areas. Within the registered species, only a few are historically related to conserved forest areas, such as Fountainea ryphea, Heraclides astyalus, Lycorea halia and Memphis moruus. The low presence of species of forested areas could be explained by the high level of fragmentation of forests in La Honda basin, and it highlights the urgent need to reforest deteriorated areas and protect some remnants that still exist. It is important to highlight the presence of Pseudoscada timma which has a restricted distribution between Colombia and Venezuela, Forsterinaria inornata endemic species for Colombia and Eumaeus godartii whose host, Zamia encephalartoides (Zamiaceae), is an endemic plant of the dry forest near the Chicamocha canyon (González, 2004).
In the localities of Tropical dry forest (bs-T) samplings, San Javier and La Purnia, were recorded six species that were not reported for this important and fragile biome by Henao-Bañol \& Gantiva (2020). In this way, the present investigation expand the list of species for dry forests of Colombia. We add to that list to Calefelis inca, Dynamine racidula, Eurema gratiosa, Leucochimona lepida, Orthos orthos and Pyrgus oileus.

\section{Analysis of inventory quality}

The potential richness according to the adjusted Clench curve was 167.13 species (Fig. 5), the proportion of observed species was $56.24 \%$, and the estimated sampling effort

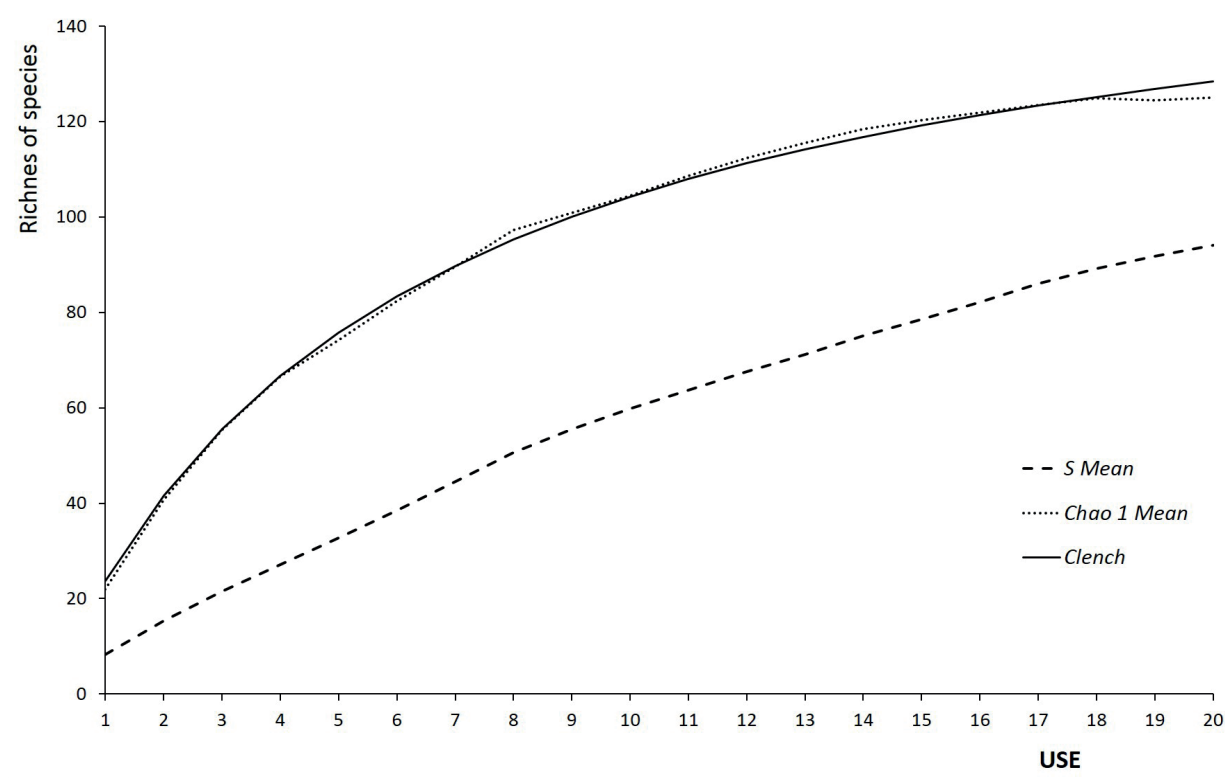

Figure 5. Analysis of inventory quality. S Mean: curve of observed richness randomized; Chao 1 Mean: curve of potential richness obtained with the nonparametric estimator Chao1; Clench: Adjusted curve to the asymptote Clench $[\mathrm{y}=(27.69 \bullet \mathrm{x}) /(1+0.17 \bullet \mathrm{x})]$; Standard error: 1.44; Coefficient of correlation: 0.99 . 
Table 1. Summary of analysis of inventory quality for each sampling site.

\begin{tabular}{cccccc}
\hline PLACES & $\begin{array}{c}\text { Observed } \\
\text { richness }\end{array}$ & $\begin{array}{c}\text { Potential } \\
\text { richness }\end{array}$ & $\begin{array}{c}\text { \% Observed } \\
\text { species }\end{array}$ & $\begin{array}{c}\text { Sampling } \\
\text { effort }\end{array}$ & $\begin{array}{c}\text { Coefficient of } \\
\text { correlation }\end{array}$ \\
\hline Cacaos & 11 & 63.81 & 17.24 & 96.40 & 0.999 \\
La Navarra & 55 & 93.56 & 75.58 & 99.97 & 0.999 \\
La Purnia & 38 & 78.55 & 26.20 & 99.30 & 0.999 \\
San Javier & 23 & 68.13 & 50.66 & 99.81 & 0.953 \\
\hline
\end{tabular}

of $99.82 \%$. With these calculated values, the sampling could be considered relatively appropriate, but also, that obviously there are species still to be reported in the sampling area. In addition, we did analysis of inventory quality in each sampling area, resulting in that all areas more collections are required to establish a list of species that represents the real richness of La Honda basin.

Although the results to La Navarra was acceptable with $75.58 \%$ of observed species (potential richness $=93.56$ ), the results for other sampling areas support the need to increase collections in the study zone, considering the possibility of making them at different season of the year. Table 1 resumes the results of analysis of inventory quality in each sampling area.

\section{Structure and composition of butterfly communities at sampling places}

Regarding the butterfly communities in the four sampling localities in La Honda basin, La Navarra presented the highest values of abundance, richness of species (observed and potential), dominance and equity (Table
2), which could be explained by the extension and quality of the forest. It stands out that the abundance of butterfly community collected in La Navarra was more equally distributed than the other localities. The comparison with other localities at similar altitudes, specifically La Tigra and Planadas in Playonero river basin (Villalobos-Moreno et al., in prep.), El Diviso and La Esperanza in Frio river basin (Villalobos-Moreno \& Salazar, 2020a) and Puente Rojo in Tona river basin (Villalobos-Moreno \& Salazar, 202ob), shows that all parameters of diversity in the four localities of La Honda basin are low, which could be explained by the high level of forest fragmentation, as well as the limited sampling effort that was established by the characterization project for this basin.

\section{Comparison between the sampling places}

The inventories comparison established that the communities of butterflies are different between the four sampling areas. A slight similarity was observed between La Navarra and La Purnia (Fig. 6), possibly because of the size and complexity of forests, but also due to the altitudinal and geographical 
Table 2. Parameters of diversity established to the sampling localities in La Honda basin, Mesa de Los Santos, Santander, Colombia, compared to localities on similar altitudes. $A b$ : Abundance; Ro: Richness observed of species; No: Richness potential of species; N 1 : Number of abundant species; $\mathcal{N}_{2}$ : Number of very abundant species.

\begin{tabular}{ccccccc}
\hline PLACES & $\begin{array}{c}\text { Altitude } \\
\text { masl }\end{array}$ & Ab & Ro & No & N1 & N2 \\
\hline Cacaos & 1,700 & 36 & 11 & 63.81 & $4.67( \pm 0.97)$ & $2.83( \pm 0.39)$ \\
La Navarra & 1,510 & 110 & 55 & 93.56 & $45.82( \pm 2.45)$ & $39.80( \pm 0.08)$ \\
La Purnia & 1,237 & 52 & 38 & 78.55 & $34.51( \pm 2.22)$ & $30.73( \pm 0.13)$ \\
San Javier & 948 & 27 & 23 & 68.13 & $21.99( \pm 1.34)$ & $20.83( \pm 0.17)$ \\
\hline La Tigra & 880 & 120 & 51 & 74.70 & $41.28( \pm 2.66)$ & $31.86( \pm 0.16)$ \\
Planadas & 1,020 & 120 & 53 & 85.11 & $40.40( \pm 2.74)$ & $31.44( \pm 0.11)$ \\
La Esperanza & 1,050 & 231 & 75 & 134.70 & $47.35( \pm 3.09)$ & $29.56( \pm 0.21)$ \\
Puente Rojo & 1,700 & 168 & 72 & 165,20 & $52.44( \pm 3.40)$ & $36.66( \pm 0,16)$ \\
El Diviso & 1,733 & 152 & 62 & 100,96 & $47.59( \pm 2.89)$ & $36.10( \pm 0.13)$ \\
\hline
\end{tabular}

proximity. Cacaos, where sampling was done in a coffee cultivation with shade and organic management, presents the biggest differences with respect to the other sampling places, which can be explained by the homogeneity of this agricultural system.

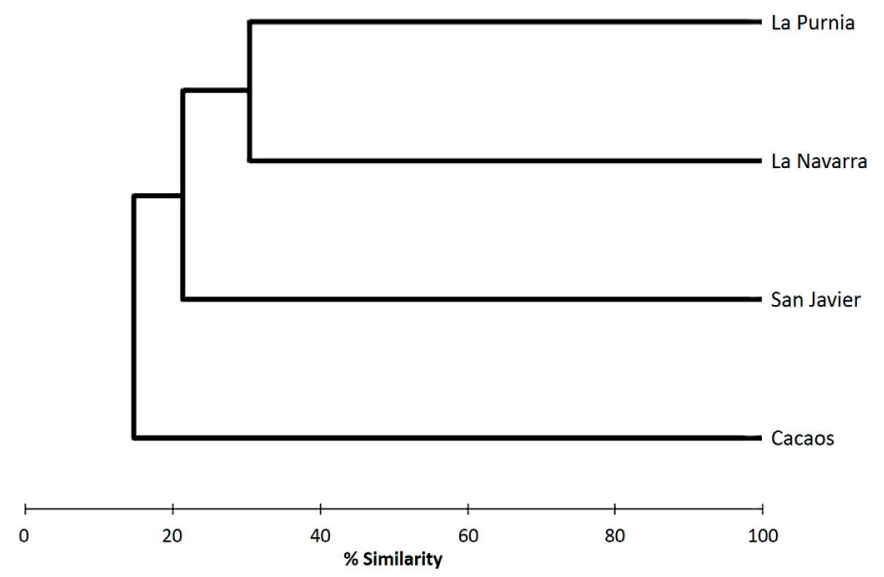

Figure 6. Analysis of Similarity between the sampling places in La Honda basin, Santander. 


\section{Conclusions}

Although the collections were not made in a specific project of lepidopterology, but in general collections of insects in the study site, the present manuscript has an important contribution to knowledge northeastern butterflies in Colombia. The analysis of inventory quality shows that there are still species to be reported to the study site, which allows proposing new samplings in the studied areas and other rural areas, as well as during different seasons. The data provided in this investigation can be an important start to carry out deepening work and as supply to establish preservation programs in the study site.

\section{Acknowledgements}

Thanks to Gonzalo Andrade-Correa in ICNUNAL for the support in the identification of species. To Julio Enrique Mantilla Serrano for the support to carry out the project of Characterization of La Honda basin. To Aldrin Darío Espinosa, Juan Carlos Hernández and Edgar Bueno for the field and lab work. To Abril-Pedraza family for the hospitality in the sampling days. To John Jairo Díaz Alyson Hatfiel and Luz Stella Amaya for the observations to this manuscript. Special thanks to Daniel "Hawk" Ramírez for the invaluable contributions in the development and analysis of this investigation, without you, science would not be the same. To Reis!

Appendix 1. List of species of butterflies and categories. N: Total abundance,

CT: Category. A: Abundant, C: Common, E: Scarce, R: Rare.

\begin{tabular}{cccc}
\hline Family & Specie & N & CT \\
\hline Hesperiidae & Chioides catillus catillus (Cramer, 1779) & E \\
\hline Cogia sp. & 1 & $\mathrm{R}$ \\
Dalla sp. & 1 & $\mathrm{R}$ \\
Heliopetes arsalte (Linnaeus, 1758) & 2 & $\mathrm{E}$ \\
Heliopetes laviana (Hewitson, 1868) & 1 & $\mathrm{R}$ \\
Orthos orthos (Godman, 1900) & 2 & $\mathrm{E}$ \\
Pyrgus oileus (Linnaeus, 1767) & 5 & $\mathrm{E}$ \\
Pyrrhopyge aziza Hewitson, 1866 & 2 & $\mathrm{E}$ \\
Urbanus dorantes (Stoll, 1790) & 4 & $\mathrm{E}$ \\
Urbanus simplicius (Stoll, 1790) & 6 & $\mathrm{E}$ \\
Vettius coryna (Hewitson, 1866) & 1 & $\mathrm{R}$ \\
\hline
\end{tabular}




\begin{tabular}{|c|c|c|c|}
\hline \multirow[t]{5}{*}{ Papilionidae } & Battus polydamas polydamas (Linnaeus, 1758) & 4 & $\mathrm{E}$ \\
\hline & Heraclides anchisiades ideaus (Fabricius, 1793) & 1 & $\mathrm{R}$ \\
\hline & Heraclides astyalus (Godart, 1819) & 1 & $\mathrm{R}$ \\
\hline & Heraclides paeon (Boisduval, 1836) & 1 & $\mathrm{R}$ \\
\hline & Heraclides thoas (Linnaeus, 1771) & 2 & $\mathrm{E}$ \\
\hline \multirow[t]{15}{*}{ Pieridae } & Ascia monuste (Linnaeus, 1764) & 4 & $\mathrm{E}$ \\
\hline & Eurema albula (Cramer, 1785) & 5 & $\mathrm{E}$ \\
\hline & Eurema daira (Godart, 1819) & 2 & $\mathrm{E}$ \\
\hline & Eurema elathea (Cramer, 1778) & 1 & $\mathrm{R}$ \\
\hline & Eurema gratiosa (Doubleday, 1847) & 1 & $\mathrm{R}$ \\
\hline & Eurema phiale (Cramer, 1775) & 2 & $\mathrm{E}$ \\
\hline & Melete lycimnia (Cramer, 1777) & 1 & $\mathrm{R}$ \\
\hline & $\begin{array}{c}\text { Dismorphia amphione praxinoe (Rosenberg } \& \text { Talbot, } \\
1914 \text { ) }\end{array}$ & 1 & $\mathrm{R}$ \\
\hline & Dismorphia crisia foedora (Lucas, 1852) & 1 & $\mathrm{R}$ \\
\hline & Phoebis philea philea (Linnaeus, 1763) & 1 & $\mathrm{R}$ \\
\hline & Phoebis sennae marcellina (Cramer, 1758) & 4 & $\mathrm{E}$ \\
\hline & Pseudopieris nehemia nehemia (Boisduval, 1836) & 1 & $\mathrm{R}$ \\
\hline & $\begin{array}{l}\text { Pseudopieris viridula viridula (C. Felder \& R. Felder, } \\
1861)\end{array}$ & 1 & $\mathrm{R}$ \\
\hline & Pyrisitia proterpia (Fabricius, 1775) & 2 & $\mathrm{E}$ \\
\hline & Pyrisitia venusta (Boisduval, 1836) & 7 & C \\
\hline \multirow[t]{6}{*}{ Lycaenidae } & Apuecla sp. & 5 & $\mathrm{E}$ \\
\hline & Arawacus togarna (Hewitson, 1867) & 1 & $\mathrm{R}$ \\
\hline & Eumaeus godartii (Boisduval, 1870) & 1 & $\mathrm{R}$ \\
\hline & Hemiargus hanno (Stoll, 1790) & 2 & $\mathrm{E}$ \\
\hline & Leptotes cassius (Cramer, 1775) & 2 & $\mathrm{E}$ \\
\hline & Rekoa meton (Cramer, 1779 ) & 1 & $\mathrm{R}$ \\
\hline
\end{tabular}




\begin{tabular}{|c|c|c|c|}
\hline \multirow[t]{4}{*}{ Riodinidae } & Calephelis inca McAlpine, 1971 & 2 & $\mathrm{E}$ \\
\hline & Esthemopsis clonia C. Felder \& R. Felder, 1865 & 2 & $\mathrm{E}$ \\
\hline & Leucochimona lepida (Godman \& Salvin, 1885) & 1 & $\mathrm{R}$ \\
\hline & Melanis marathon (C. Felder \& R. Felder, 1865) & 4 & $\mathrm{E}$ \\
\hline \multirow[t]{25}{*}{ Nymphalidae } & Actinote parapheles Jordan, 1913 & 4 & $\mathrm{E}$ \\
\hline & Actinote pellenea equatoria (H. Bates, 1864) & 4 & $\mathrm{E}$ \\
\hline & Adelpha alala completa Fruhstorfer, 1907 & 2 & $\mathrm{E}$ \\
\hline & Adelpha irmina tumida (A. Butler, 1873) & 1 & $\mathrm{R}$ \\
\hline & Anartia amathea (Linnaeus, 1758) & 2 & $\mathrm{E}$ \\
\hline & Anartia jatrophae (Linnaeus, 1763) & 1 & $\mathrm{R}$ \\
\hline & Archaeoprepona demophon (Linnaeus, 1758) & 1 & $\mathrm{R}$ \\
\hline & Castilia ofella (Hewitson, [1864]) & 2 & $\mathrm{E}$ \\
\hline & Catonephele numilia (Cramer, 1775) & 1 & $\mathrm{R}$ \\
\hline & Catonephele nyctimus (Westwood, 1850) & 2 & $\mathrm{E}$ \\
\hline & Chlosyne lacinia (Geyer, 1837) & 2 & $\mathrm{E}$ \\
\hline & Cissia terrestris (A. Butler, 1867) & 1 & $\mathrm{R}$ \\
\hline & Colobura dirce (Linnaeus, 1758) & 2 & $\mathrm{E}$ \\
\hline & Danaus gilippus (C. Felder \& R. Felder, 1865) & 1 & $\mathrm{R}$ \\
\hline & Diaethria clymena dodone (Guenée, 1872) & 1 & $\mathrm{R}$ \\
\hline & Doxocopa pavon (Latreille, [1809]) & 1 & $\mathrm{R}$ \\
\hline & Dryadula phaetusa (Linnaeus, 1758) & 1 & $\mathrm{R}$ \\
\hline & Dryas iulia (Fabricius, 1775) & 2 & $\mathrm{E}$ \\
\hline & Dynamine agacles (Dalman, 1823) & 2 & $\mathrm{E}$ \\
\hline & Dynamine artemisia (Fabricius, 1793) & 1 & $\mathrm{R}$ \\
\hline & Dynamine racidula (Hewitson, 1852) & 6 & $\mathrm{E}$ \\
\hline & Episcada salvinia apia (C. Felder \& R. Felder, 1865) & 1 & $\mathrm{E}$ \\
\hline & Euptoieta claudia (Cramer, 1775) & 1 & $\mathrm{R}$ \\
\hline & Euptychoides saturnus (Butler, 1867) & 26 & A \\
\hline & Forsterinaria inornata (C. Felder \& R. Felder, 1867) & 4 & $\mathrm{E}$ \\
\hline
\end{tabular}




\begin{tabular}{|c|c|c|}
\hline Fountainea ryphea ryphea (Cramer, 1775) & 3 & $\mathrm{E}$ \\
\hline Greta andromica andromica (Hewitson, $[1855]$ ) & 1 & $\mathrm{R}$ \\
\hline Hamadryas feronia (Linnaeus, 1758) & 1 & $\mathrm{R}$ \\
\hline Hamadryas fornax (Hübner, [1823]) & 1 & $\mathrm{R}$ \\
\hline Heliconius charithonia (Linnaeus, 1767) & 2 & $\mathrm{E}$ \\
\hline Heliconius clysonimus Latreille, [1817] & 3 & $\mathrm{E}$ \\
\hline Heliconius cydno cydno (E. Doubleday, 1847) & 3 & $\mathrm{E}$ \\
\hline Heliconius erato hydara (Hewitson, 1867) & 1 & $\mathrm{R}$ \\
\hline Heliconius hecale anderida (Hewitson, [1853]) & 2 & $\mathrm{E}$ \\
\hline Heliconius melpomene (Linnaeus, 1758) & 2 & $\mathrm{E}$ \\
\hline Hermeuptychia hermes (Fabricius, 1775) & 11 & A \\
\hline Hyposcada virginiana neustetteri Bargmann, 1928 & 2 & $\mathrm{E}$ \\
\hline Funonia evarete (Cramer, 1779) & 3 & $\mathrm{E}$ \\
\hline Lycorea halia atergatis Doubleday (1847) & 1 & $\mathrm{R}$ \\
\hline Magneuptychia libye (Linnaeus, 1767) & 1 & $\mathrm{R}$ \\
\hline Marpesia chiron (Fabricius, 1775) & 1 & $\mathrm{R}$ \\
\hline Mechanitis menapis Hewitson, [1856] & 2 & $\mathrm{E}$ \\
\hline Megeuptychia antonoe (Cramer, 1775) & 5 & $\mathrm{E}$ \\
\hline Memphis moruus phila (H. Druce, 1877) & 2 & $\mathrm{E}$ \\
\hline Morpho helenor peleides Kollar, 1850 & 2 & $\mathrm{E}$ \\
\hline Nica flavilla (Godart, [1824]) & 1 & $\mathrm{R}$ \\
\hline Oressinoma typhla E. Doubleday, [1849] & 3 & $\mathrm{E}$ \\
\hline Pareuptychia ocirrhoe (Fabricius, 1776) & 1 & $\mathrm{R}$ \\
\hline Pedaliodes phrasis Grose-Smith, 1900 & 1 & $\mathrm{R}$ \\
\hline Pseudoscada timna ssp. & 2 & $\mathrm{E}$ \\
\hline Pteronymia latilla latilla (Hewitson, [1855]) & 1 & $\mathrm{R}$ \\
\hline Pteronymia aletta aletta (Hewitson, [1855]) & 1 & $\mathrm{R}$ \\
\hline Tegosa anieta (Hewitson, 1864) & 3 & $\mathrm{E}$ \\
\hline Vanessa virginiensis (Drury, 1773) & 1 & $\mathrm{R}$ \\
\hline
\end{tabular}


Appendix 2. Some butterflies collected in La Honda basin, Mesa de Los Santos, Santander, Colombia. Scale $=1 \mathrm{~cm}$.
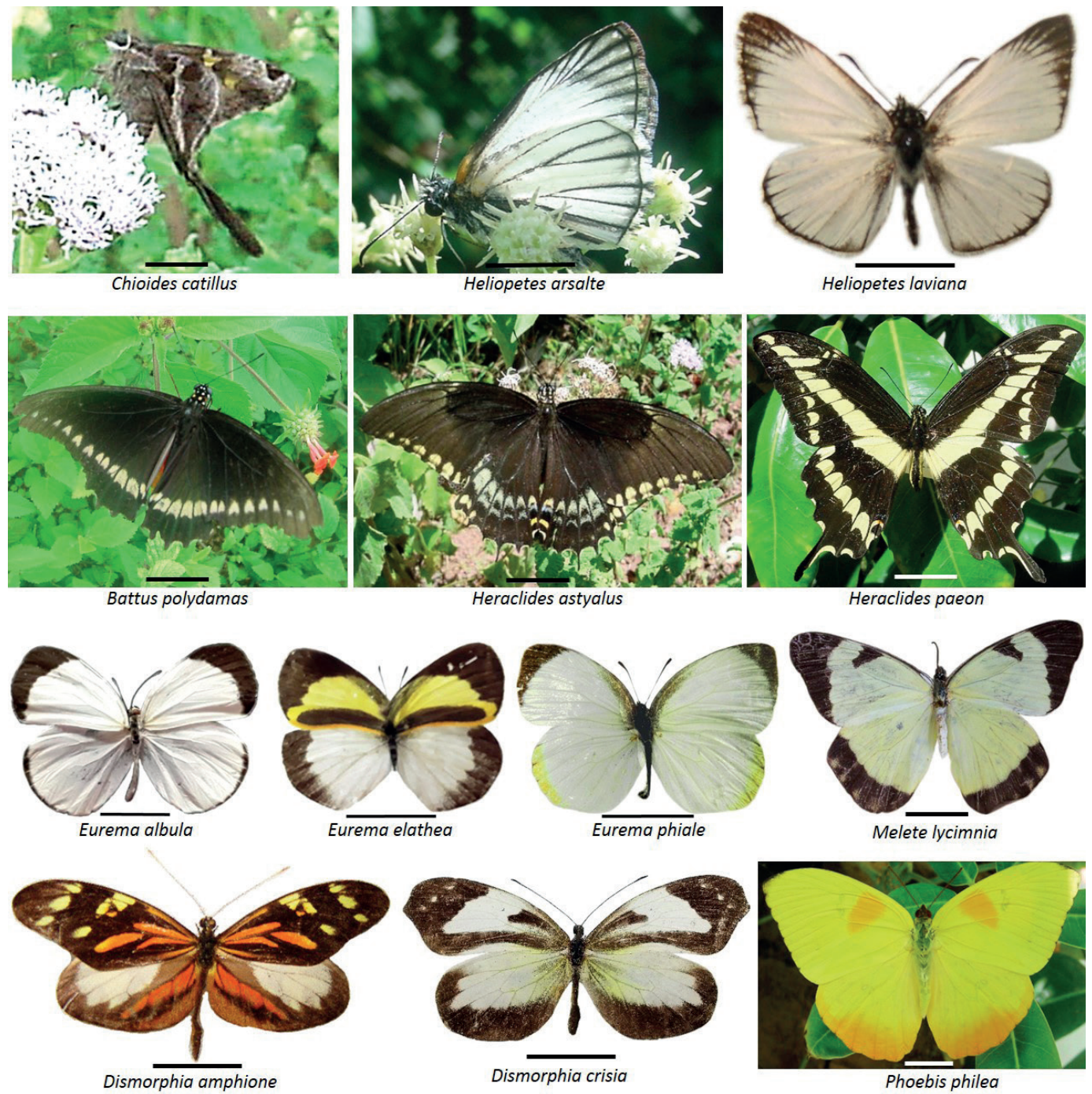

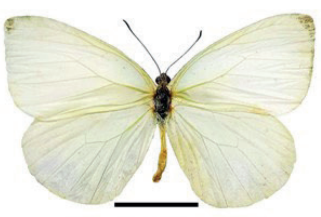

Pseudopieris nehemia

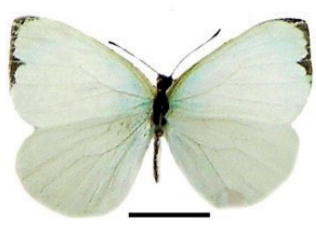

Pseudopieris viridula

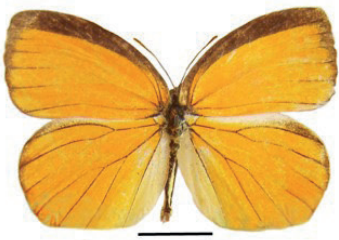

Pyrisitia proterpia

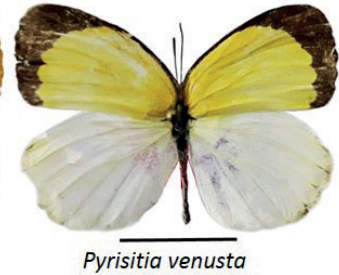

Pyrisitia venusta 

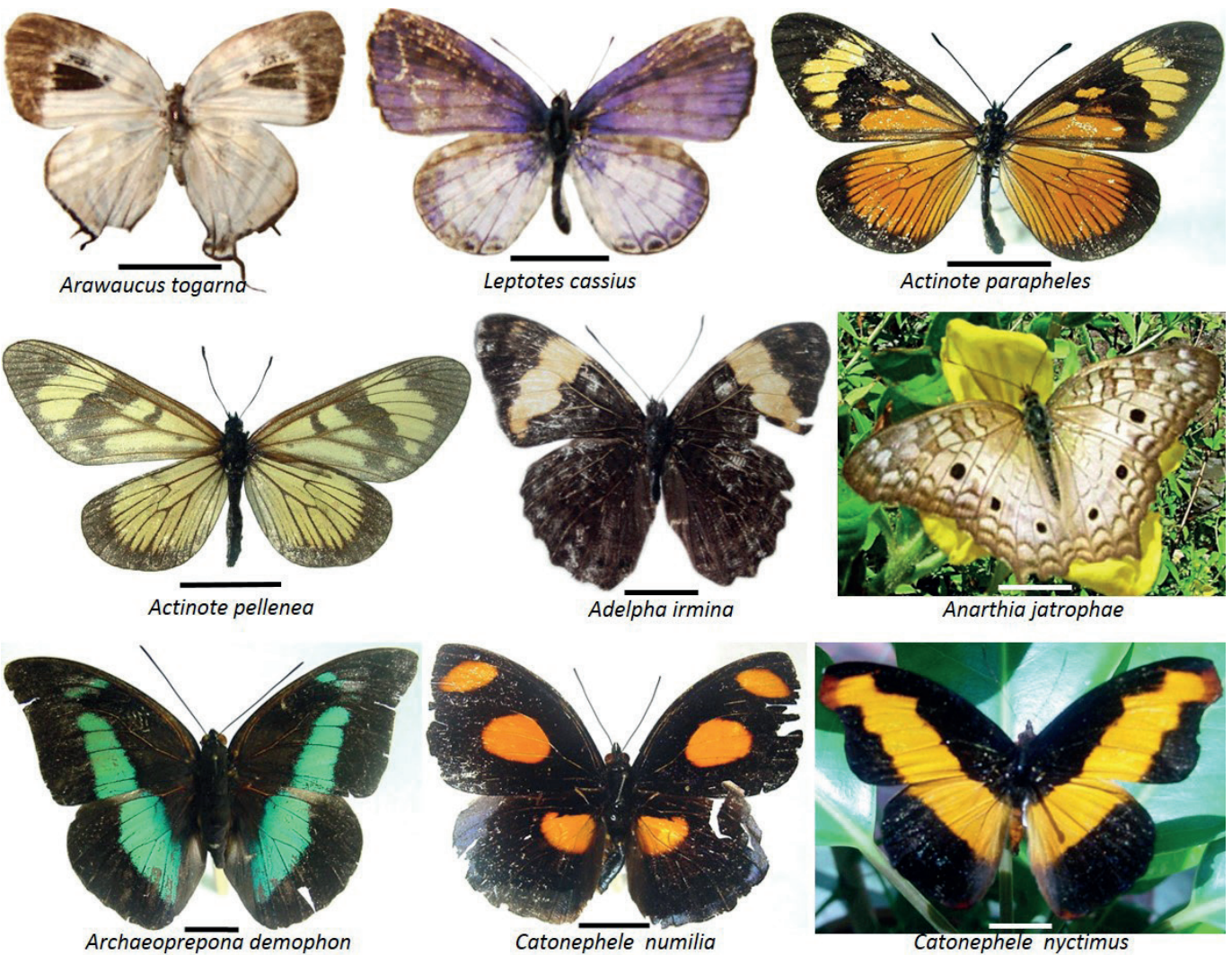

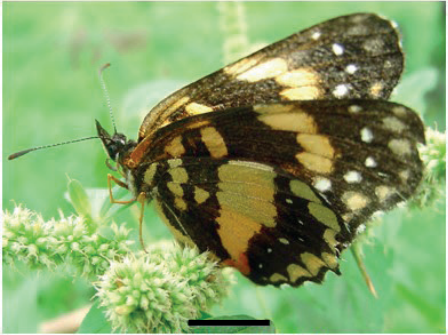

Chlosyne lacinia

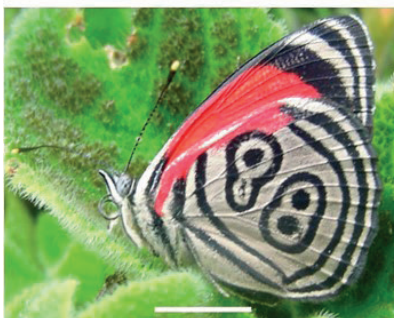

Diaethria clymena

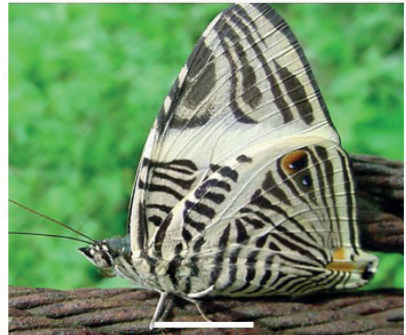

Colobura dirce

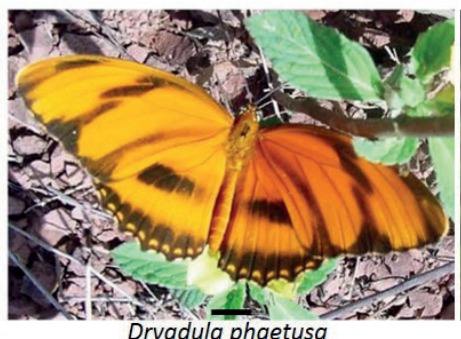
Dryadula phaetusa

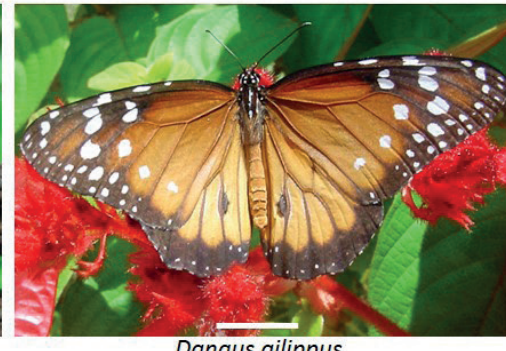

Danaus gilippus

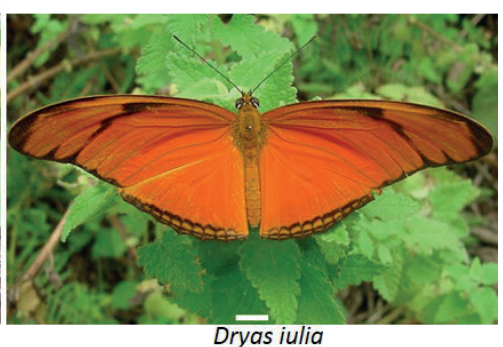




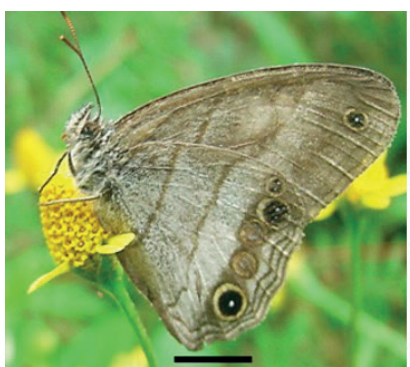

Euptychoides saturnus

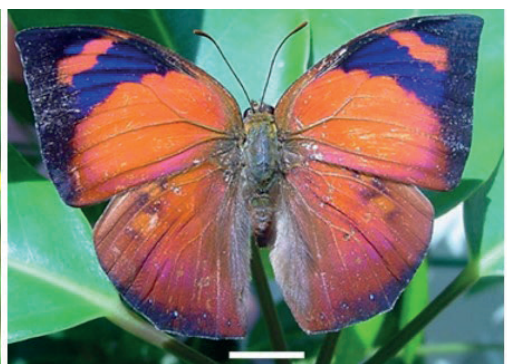

Fountainea ryphea

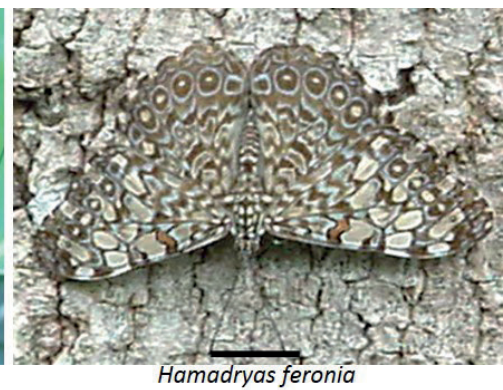

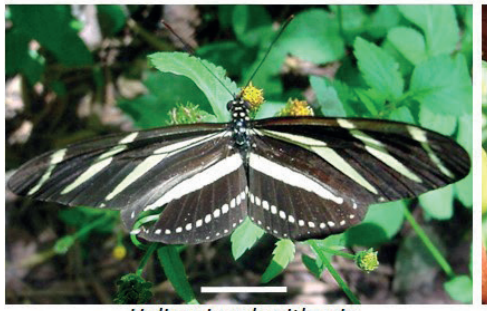

Heliconius charithonia

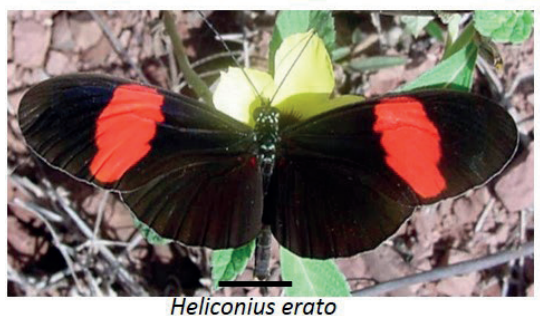

Heliconius erato

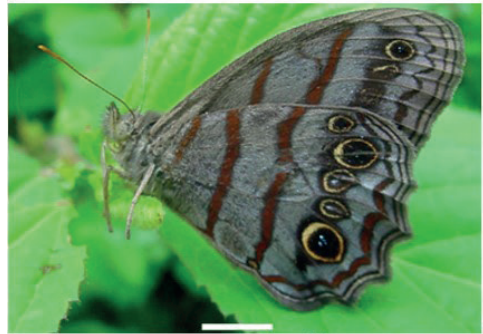

Magneuptychia libye
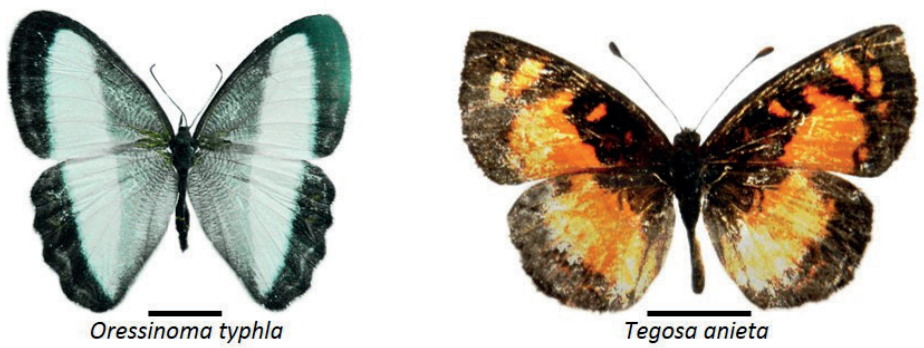

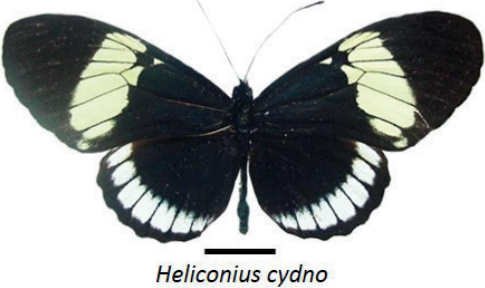

Heliconius clysonimus
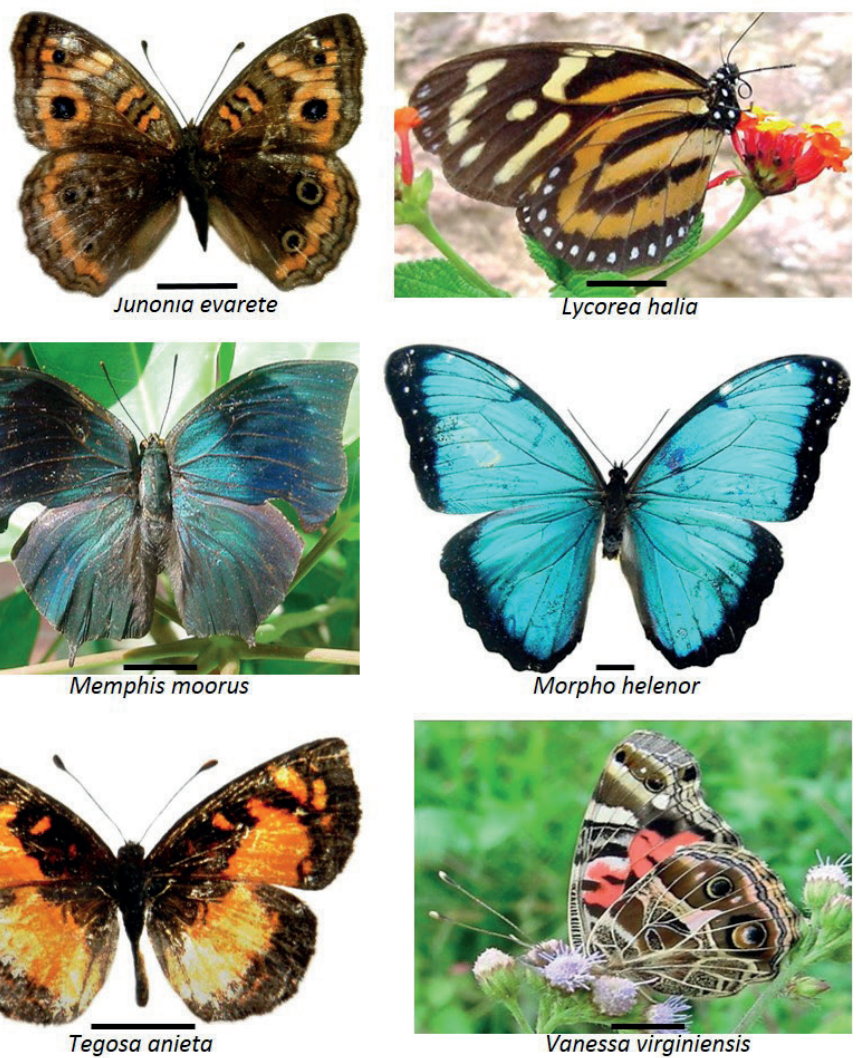


\section{References}

Agudelo-M.,J. C. and Pérez-Buitrago, N. 2015. Notas acerca de la distribución de Papilionidae (Lepidoptera: Papilionoidea) en el norte de la Orinoquia colombiana. Boletín Científico Museo Historia Natural Universidad de Caldas, 19(1): 203-214.

Andrade-C., M. G. 1990. Clave para las familias y subfamilias de Lepidóptera Rhopalocera de Colombia. Caldasia, 16(77): 197-200.

Andrade-C., M. G. 2011. Estado del conocimiento de la biodiversidad en Colombia y sus amenazas. Consideraciones para fortalecer la interacción ambiente-política. Revista Academia Colombiana de Ciencias, 35: 491-507.

Arbeláez-Cortez, E. 2013. Knowledge of Colombian biodiversity: Published and indexed. Biodiversity and Conservation, 22: 2875-2906.

Brown, K. S.,Jr. 1991. Conservation of Neotropical environments: Insects as indicators. Pp 349-404. In: Collins, N. M. and Thomas, J. A. (Ed.). Conservation of Insects and their Habitats. Academic Press, London. 449 pp.

Brown, Jr. K. S. and Freitas, A. V. L. 2002. Butterfly communities of urban forest fragments in Campinas, Sao Pablo, Brazil: structure, instability, environmental correlates, and conservation. Fournal of Insect Conservation, 6: 217-231.

Calderón-Rueda, J. C. 2011. Quebrada la Honda del municipio de Los Santos Santander, un laboratorio pedagógico para el bienestar de la comunidad rural La Granja. Master work. Universidad Nacional de Colombia. Bogotá, Colombia. 101 pp.

Campos-Salazar, L. R., Gómez-Bulla, J. and Andrade-C, M. G. 2011. Mariposas (Lepidoptera: Hesperioidea-Papilionoidea) de las áreas circundantes a las ciénagas del departamento de Córdoba, Colombia. Revista Academia Colombiana de Ciencias, 35: 45-60. 
Casas-Pinilla, L. C., Mahecha-J., O., Dumar-R., J. C. and Ríos-Málaver, I. C. 2017. Diversidad de mariposas en un paisaje de bosque seco tropical, en la Mesa de los Santos, Santander, Colombia (Lepidoptera: Papilionoidea). SHILAP Revta. lepid., 45 (177): 83-108.

Chao, A \& Shen, T. J. 2009. Program SPADE (Species prediction and diversity estimation). Access date: 25 Aug. 2019. Available in: http://chao.stat.nthu.edu.tw

Colwell, R. K. [Internet]. 2000. EstimateS v. 6.ob1. Access date: 20 Aug. 2019. Available in: http://viceroy.eeb.uconn. edu/EstimateS

Constantino, L. M. 1997. Lepidópteros diurnos del Chocó biogeográfico: diversidad, alternativas productivas $y$ estrategias de conservación. Pp 47-74. Memories XXIV CONGRESO SOCIEDAD COLOMBIANA DE ENTOMOLOGÍA. Pereira, Colombia. 218 pp.

Cuatrecasas, J. 1989. Aspectos de la vegetación natural en Colombia. Pérez-Arbeláezia, 2(8): 155-289.DeVries, P. 1987. The Butterflies of Costa Rica and their natural history, Papilionidae, Pieridae, Nymphalidae. Princenton University Press, Princeton. 327 pp.

Fagua, G. 1996. Comunidad de mariposas y artropofauna asociada con el suelo de tres tipos de vegetación de la Serranía de Taraira (Vaupés, Colombia). Una prueba del uso de mariposas como bioindicadores. Revista Colombiana de Entomología, 22(3): 143-151.

González, F. A. 2004. Herbovoría en una gimnosperma endémica de Colombia, Zamia encephalartoides (Zamiaceae) por parte de Eumaeus (Lepidoptera: Lycaenideae). Revista Academia Colombiana de Ciencias Exactas, 28(107): 233-243.

Gotelli, N. and Colwell, R. K. 2001. Quantifying biodiversity: Procedures and pitfalls in the measurement and comparison of species richness. Ecology Letters, 4: 379-391. 
Henao, E. 2006. Aproximación a la distribución de mariposas del departamento de Antioquia (Papilionidae, Pieridae y Nymphalidae: Lepidoptera) con base en zonas de vida. Boletín Científico Museo Historia Natural Universidad de Caldas, 10: 279-312.

Henao, E. and Stiles, F. 2018. Un inventario de las mariposas diurnas (Lepidoptera: Hesperioidea-Papilionoidea) de dos reservas altoandinas de la Cordillera Oriental de Colombia. Revista Facultad Ciencias, 7(1): 71-87.

Holdridge, L. R. 2000. Ecología basada en zonas de vida. Instituto Interamericano de Cooperación para la Agricultura, San José, Costa Rica. 216 pp.

Huertas, B. and Arias, J. J. 2007. A new butterfly species from the Colombian Andes and a review of the taxonomy of the genera Idioneurula Strand, 1932 and Tamania Pyrcz, 1995 (Lepidoptera: Nymphalidae: Satyrinae). Zootaxa, 1652: 27-40.

Hyams, D. [Internet]. 2009. CurveExpert v1.40. Access date: 25 Aug. 2019. Available in: http://www.curveexpert.net/

Jiménez-Valverde, A. and Hortal, J. 2003. Las curvas de acumulación de especies y la necesidad de evaluar la calidad de los inventarios biológicos. Revista Ibérica de Aracnología, 8: 151-161.

Jost, L. 2010. The relation between Evenness and Diversity. Diversity, 2: 207-232.

Kremen, C. 1992. Assessing the indicator properties of assemblages for natural areas monitoring. Ecological Applications, 2(2): 203-217.

Kremen, C. 1994. Biological inventory using target taxa: a case study of the butterflies of Madagascar. Ecological Applications, 4: 407-22. 
Kremen, C., Merenlender, A. M. and Murphy, D. D. 1994. Ecological monitoring: a vital need for integrated conservation and development programs in the tropics. Conservation Biology, 8: 388-97.

Lamas, G. 2004. Checklist of Neotropical Lepidoptera, Part 4A, Hesperioidea- Papilionoidea. Association for Tropical Lepidoptera. Gainesville, USA. 439 pp.

Le Crom, J. F., Constantino, L. M. and Salazar, J. A. 2002. Mariposas de Colombia, Papilionidae. Carlec Ltda., Bogotá, Colombia. 119 pp.

Le Crom, J. F., Constantino, L. M. and Salazar, J. A. 2004. Mariposas de Colombia, Pieridae. Carlec Ltda., Bogotá, Colombia. 113 pp.

Llorente, B. J. and Martínez, A. L. 1998. Análisis conservacionista de las mariposas mexicanas Papilionidae (Lepidoptera, Papilionoidea). Pp 149-178. In: Ramamoorthy, T. P., Bye, R., Lot, A. and Fa, J. Diversidad Biológica de México: orígenes y distribución. Instituto de Biología, Universidad Nacional Autónoma de México, México. 291 pp.

Ludwig, J. A. and Reynolds, J. F. 1988. Statistical ecology: a primer in methods and computing. Wiley Interscience Pub., New York, USA. 368 pp.

Magurran,A.E. 1988. Ecological diversity andits measurement. Princeton University Press, New Jersey, USA. 179 pp.

Maso, A. and Piojan, M. 1997. Observar mariposas. Editorial Planeta, Madrid, España. 317 pp.

Moreno, C. E., Barragán, F., Pineda, E. and Pavón, N. P. 2011. Reanálisis de la diversidad alfa: alternativas para interpretar y comparar información sobre comunidades ecológicas. Revista Mexicana de Biodiversidad, 82: 1249-126. 
Neild, A. 1996. The butterflies of Venezuela. Part I: Nymphalidae I (Limenitidinae, Apaturinae, Charaxinae). Meridian Publications, London, UK. 144 pp.

Neild, A. 2008. The butterflies of Venezuela. Part II: Nymphalidae II (Acraeinae, Libytheinae, Nymphalinae, Ithomiinae and Morphinae). Meridian Publications, London, UK. 149 pp.

Núñez, R. and Barro, A. 2003. Composición y estructura de dos comunidades de mariposas (Lepidoptera: Papilionoidea) en Boca de Canasi, La Habana, Cuba. Revista Biología, 17(1): $8-17$.

Oliver, I. and Beattie, A. J. 1996. Designing a cost-effective invertebrate survey: a test of methods for rapid assessment of biodiversity. Ecological Applications, 6: 594-607.

Ospina-López, L. A. 2014. Estructura de la comunidad de mariposas diurnas (Lepidoptera: Hesperioidea y Papilionoidea) en distintos tipos de hábitats en la cuenca del río Lagunillas (Tolima - Colombia). Degree work, Universidad Nacional de Colombia, Bogotá, Colombia. 110 pp.

Palacios, M. and Constantino, L. M. 2006. Diversidad de lepidópteros Rhopalocera en un gradiente altitudinal en la Reserva Natural El Pangan, Nariño, Colombia. Boletín Científico Museo de Historia Natural Universidad de Caldas, 10: 258-278.

Pardo-Locarno, L. C. and Villalobos-Moreno, A. 2016. Chiasognathini colombianos: Redescripción y adiciones a la distribución de Sphaenognathus rotundatus Lacroix y Sphaenognathus prionoides Buquet (Coleoptera: Lucanidae). Boletín Científico Museo de Historia Natural Universidad de Caldas, 20(2): 217-231.

Primer Ltd. [Internet]. 2006. PRIMER 6. Access date: 25 Aug. 2019. Available in: http://www.primer-e.com/ 
Ramírez, L., Chacón, P. and Constantino, L. M. 2007. Diversidad de mariposas diurnas (Lepidóptera: Papilionoidea y Hesperoidea) en Santiago de Cali, Valle del Cauca, Colombia. Revista Colombiana de Entomología, 3(1): 54-63.

Rangel-CH., J. O. 1995. Colombia diversidad biótica I. clima, Centros de concentración de especies, fauna. Instituto de Ciencias Naturales, Universidad Nacional de Colombia, Bogotá, Colombia. 442 pp.

Triplehorn, C. H. and Johnson, N. F. 2005. Borror and DeLong's Introduction to the study of insects. 7 th Ed. Thomson Brooks/Cole, USA. 864 pp.

Villalobos-Moreno, A. 2013. Nueva especie de mariposa (Lepidoptera, Nymphalidae, Satyrinae) para los Andes colombianos. Boletín Científico Museo de Historia Natural Universidad de Caldas, 17(1): 268-275.

Villalobos-Moreno, A. 2017. Escarabajos (Coleoptera: Melolonthidae) de un robledal asociado al Parque Natural Regional de Santurbán. Doctoral thesis. Universidad Nacional de Colombia, Bogotá, Colombia. 192 pp.

Villalobos-Moreno, A., Agudelo, J. C. and Salazar-Escobar, J. (in prep.). Mariposas (Lepidoptera: Papilionidae) de un bosque seco tropical en la cuenca del río Playonero, Andes nororientales de Colombia.

Villalobos-Moreno, A., Céspedes, J. C. and Agudelo, J. C. 2012. Mariposas (Lepidoptera: Papilionidae) depositadas en las colecciones entomológicas de la CDMB y la Universidad Industrial de Santander. Revista Colombiana de Entomología, 38(1): 167-170.

Villalobos-Moreno, A., Cepeda-Olave, N. E., Pardo-Locarno, L. C. and Gómez, I.J. 2013. Contribución al conocimiento de la familia Passalidae (Coleoptera: Scarabaeoidea) en Santander, Colombia. Revista Agricultura Tropical, 36(3-4): 37-45. 
Villalobos-Moreno, A. and Gómez, I. J. 2015. Contribución a la distribución de las mariposas del género Morpho Fabricius, 1807 (Lepidoptera: Nymphalidae: Morphinae) en el nororiente del departamento de Santander (Colombia) y estudio de su genitalia. Boletín Científico Museo de Historia Natural Universidad de Caldas, 19(2): 281-289.

Villalobos-Moreno, A., Pardo-Locarno, L. C., CabreroSañudo, F. J., Ospina-Torres, R. and Gómez, I. J. 2016. Inventario preliminar de los escarabajos de la familia Melolonthidae (Coleoptera: Scarabaeoidea) en un robledal del nororiente de los Andes colombianos. Boletín de la Sociedad Entomológica Aragonesa, 58 (1): 159-167.

Villalobos-Moreno, A. and Salazar-Escobar, J. 2020a. Contribución al conocimiento de los Lepidoptera de la cuenca de río Frío, Santander, Colombia (Lepidoptera: Papilionoidea). SHILAP revta lepid., 48(189): 153-166.

Villalobos-Moreno, A. and Salazar-Escobar, J. 2020 b. Mariposas (Lepidoptera: Papilionoidea) de un bosque Andino en la vertiente oriental de la cuenca de río Tona, Santander (Colombia). Anales de Biología, 42: 75-84.

Walther, A. and Moore, J. L. 2005. The concepts of bias, precisión and accuracy, and their use in testing the performance of species richness estimators, with a literature review of estimator performance. Ecography, 28: 815-829. 